${ }^{1}$ Balıkesir Üniversitesi Tıp Fakültesi Tıbbi Patoloji Anabilim Dalı, Balıkesir, Türkiye e-posta: serpilselinbaytekin@hotmail.com ORCID: 0000-0002-4513-1018

${ }^{2}$ Balıkesir Üniversitesi Tıp Fakültesi Tıbbi Patoloji Anabilim Dalı, Balıkesir, Türkiye e-posta: gulaytr@yahoo.com.tr ORCID: 0000-0002-3702-8811

${ }^{3}$ Balıkesir Üniversitesi Tıp Fakültesi Kulak Burun Boğaz

Hastalıkları Anabilim Dalı, Balıkesir, Türkiye e-posta:

ktulaci@gmail.com ORCID: 0000-0001-6783-2133

Atıf İçin: Serpil PAKSOY, Gülay TURAN, Kamil Gökçe TULACI,

Larinkste Verruka Vulgaris: Olgu Sunumu, Balıkesir Medical Journal, 2020;4(2): 56-60

Başvuru Tarihi: 20.05.2020

Kabul Tarihi: 23.06.2020 Yayınlanma Tarihi: 23.06.2020

Sorumlu Yazar: Serpil PAKSOY, Balıkesir Üniversitesi Tıp Fakültesi Tıbbi Patoloji Anabilim Dalı, Balıkesir

\section{Larinkste Verruka Vulgaris: Olgu Sunumu}

\author{
Laryngeal Verruca Vulgaris: Case Report
}

\section{Serpil PAKSOY ${ }^{1}$, Gülay TURAN² ${ }^{2}$ Kamil Gökçe TULACI ${ }^{3}$}

\section{öz}

Verruka vulgaris HPV ile ilişkili sık görülen bir deri lezyonudur. Larinkste nadir görülür. Larinkste görülen verruka vulgaris, deride görülen verruka vulgaris ile histolojik olarak benzer özelliklere sahiptir. Benign bir lezyondur ve malign bir lezyon olan verruköz karsinomdan ayrımı tedavi açısından önem taşımaktadır. Biz burada ses kısıklığı şikâyeti ile gelen 59 yaşındaki erkek hastayı sunduk. Lezyon cerrahi olarak çıkarıldıktan sonra patoloji sonucu verruka vulgaris olarak tespit edildi.

Anahtar Kelimeler: Larinks; verruka vulgaris; HPV.

\section{ABSTRACT}

Verruca vulgaris is a common skin lesion associated with HPV. Verruca vulgaris is rarely seen in larynx. The histologic features of laryngeal verruca vulgaris are identical to those of cutaneous verruca vulgaris. It is a benign lesion and its distinction from verrucous carcinoma which is a malignant lesion is important in terms of a treatment. We present a case of a 59-year-old-man presenting with hoarseness. After the surgical removal of the lesion, the pathological finding was verruca vulgaris.

Keywords: Larynx; verruca vulgaris; HPV. 
Verruka vulgaris, HPV ile ilişkili keratinize ve keratinize olmayan epiteli tutan sık görülen bir deri hastalığıdır (1). Deride vücudun herhangi bir bölgesinde bulunabilir. Bir ya da daha fazla sayıda olup deriden kabarıklık gösteren küçük, sert lezyonlardır. Nadiren başlıca dudak ve oral kavite olmak üzere mukozal membranları tutabilir (2). Larinks tutulumu ise oldukça nadirdir (3).

Laringeal verruka vulgaris erişkin yaşlarda ve erkeklerde kadınlardan daha sık görülür. Larinkste sıklıkla vokal kordları tutar. En sık belirtisi ses kısıklı̆ı̆ıı. Makroskopik olarak yüzeyden kabarıklık gösteren genelde 1 cm'den küçük boyutta gri beyaz renkli lezyonlar şeklindedir. Mikroskopik incelemede verrukoid görünüm, keratozis, belirgin granüler tabaka, kaba ve düzensiz keratohiyalin granüller, ince reteler içerir ve histolojik görünümü deride görülen verruka vulgaris ile benzerdir (4). Tanısı verrüköz karsinom ve papiller skuamöz hücreli karsinom ile karışabileceği için önemlidir.

\section{OLGU SUNUMU}

59 yaşında erkek hasta Balıkesir Üniversitesi Tıp Fakültesi Kulak Burun Boğaz polikliniğine ses kısıklı̆ı şikâyeti ile başvurmuştur. Özgeçmişinde sigara ya da alkol kullanma öyküsü bulunmamaktadır. Daha önce ailesinde ya da kendisinde deride ya da oral mukozada geçirilmiş viral vart öyküsü bulunmamaktadır. Yapılan endoskopik laringeal incelemede sağ vokal kord orta kesimde lökoplazi alanı izlenmiştir. Lezyon cerrahi operasyon ile eksize edilmiştir.

Materyalin makroskopik incelemesinde en büyüğü $7 \times 4 \times 2 \mathrm{~mm}$ boyutlarda parçalı olarak gönderilmiş gri beyaz renkli polipoid dokular izlendi. Mikroskopik incelemede papillomatoz, parakeratoz, hiperkeratoz, kaba keratohiyalin granülleri içeren belirgin granüler tabakası bulunan akantotik epitel ile döşeli az sayıda koilositik değişikliklerin de görüldüğü lezyon izlendi. Bu bulgular ile lezyona verruka vulgaris tanısı verildi. Tedavi sonrası herhangi bir komplikasyon izlenmedi.

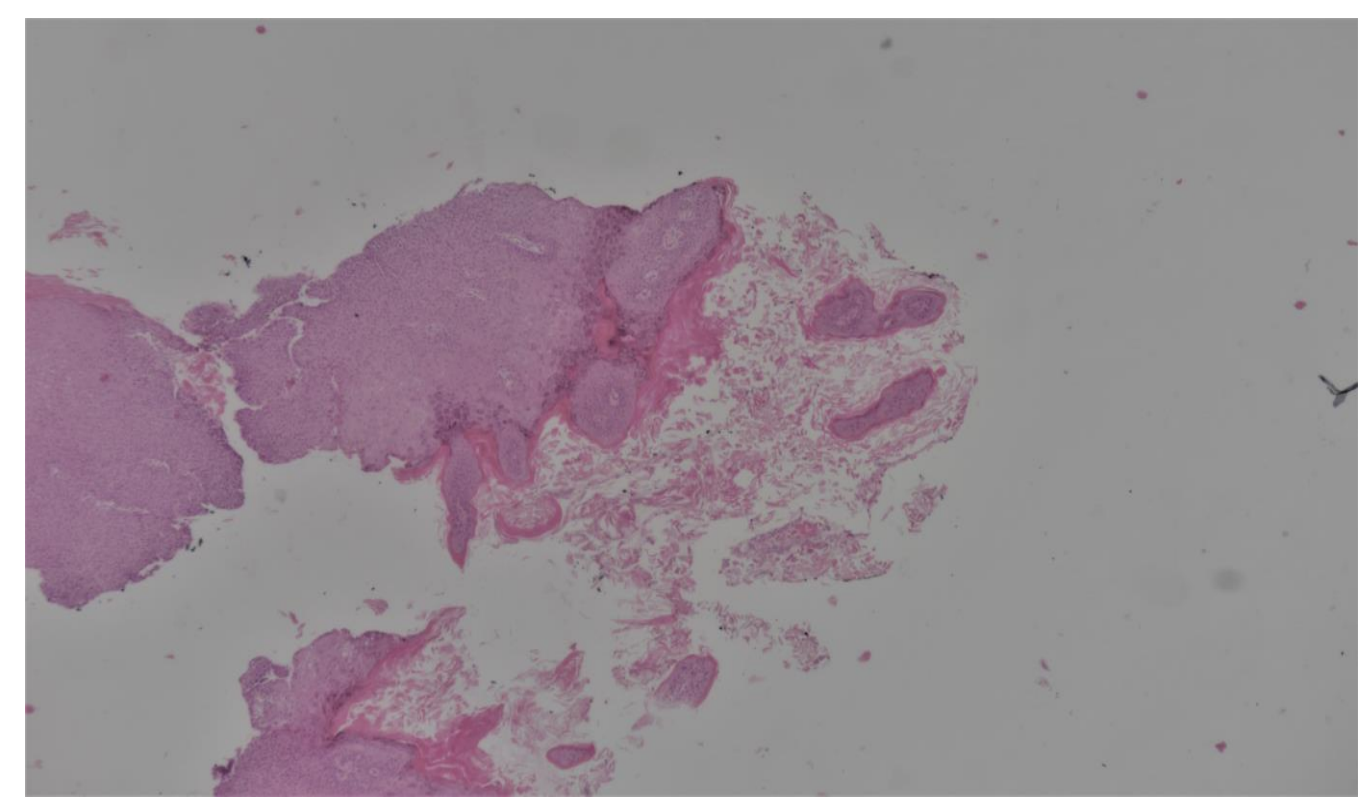

Resim 1. Hiperkeratoz ve hipergranülosis içeren papiller yapılar ile uzamış reteler içeren verruka vulgarisin küçük büyütmede mikroskopik görüntüsü H\&EX4O. 


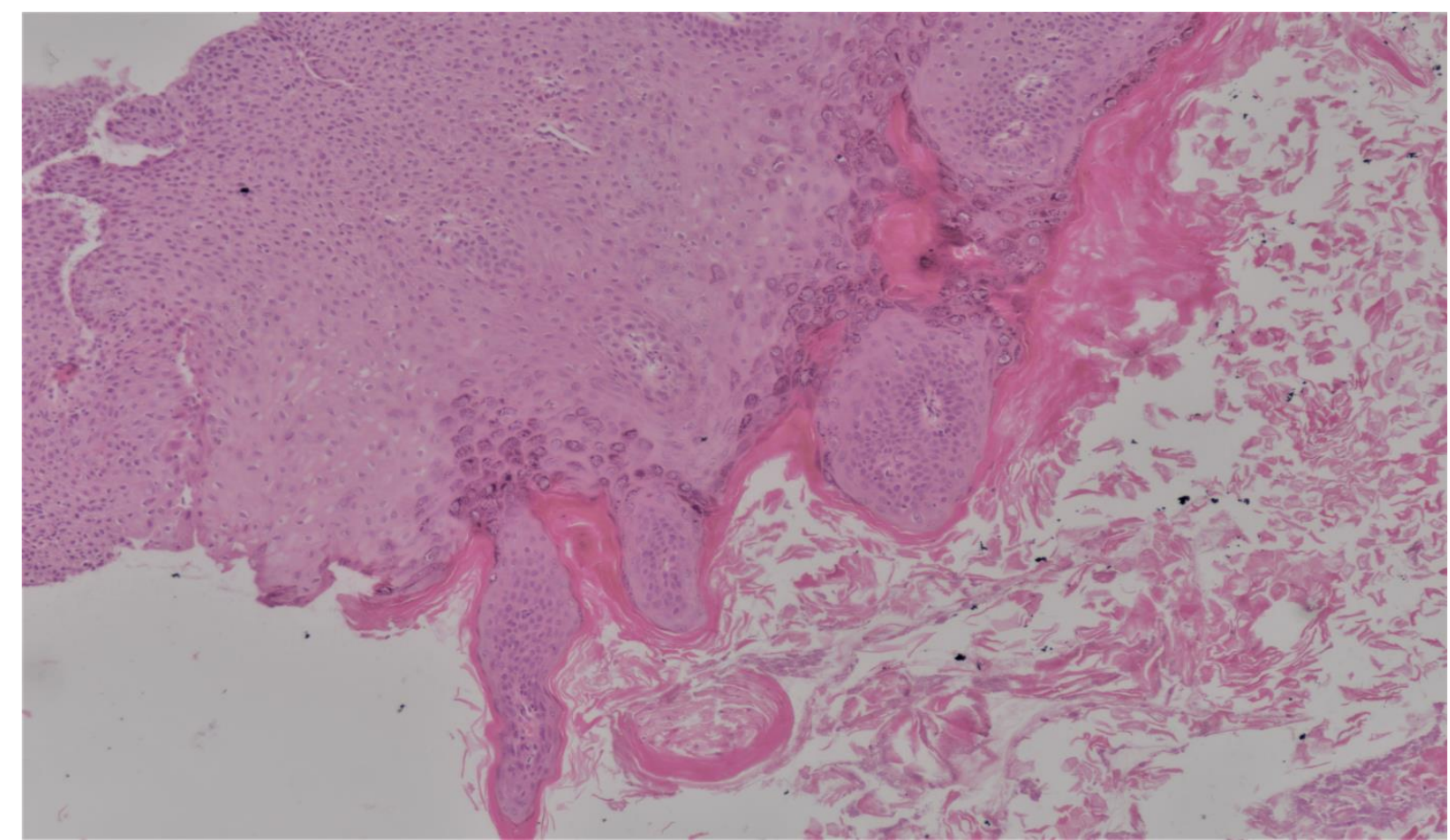

Resim 2. Verruka vulgarisin büyük büyütmede mikroskopik görüntüsü H\&EX100.

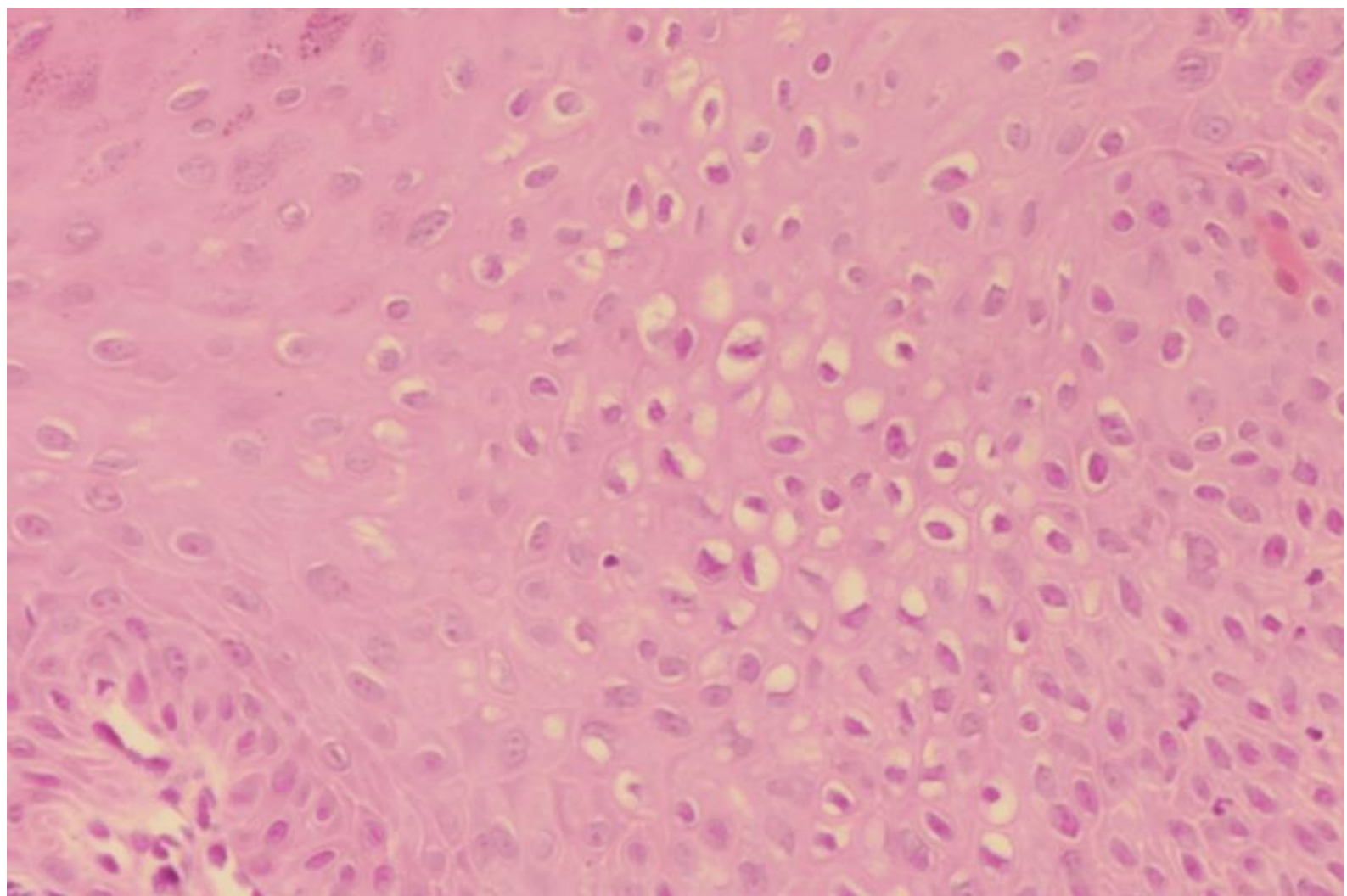

Resim 3. Büyük büyütmede koilositik değișiklikler içeren verruka vulgarisin mikroskopik görüntüsü H\&EX200.

\section{TARTIŞMA}

Human papilloma virüs, küçük $55 \mathrm{~nm}$ çapında 8000 baz uzunluğunda ikozahedral çift zincirli bir DNA virüsüdür. 50’ den fazla tipi tanımlanmıştır (5). HPV verruka planus, verruka plantaris ve kondiloma aküminatayı da içeren deri ve mukozayı etkileyen lezyonlar ile ilişkilidir. HPV epitelyotropik bir virüs olup deri, genitoüriner sistem, üst solunum yolları ve gastrointestinal sistem mukozasını tutar. Dudak ve oral kaviteyi tutan verruka 
vulgaris, başlıca HPV tip 4 ve daha az sıklıkla tip 2 ile ilişkilidir (6,7). HPV tip 6 ve 11 ile ilişkili olan laringeal verruka vulgaris ise oldukça nadir görülen bir durumdur (8).

Skuamöz papillom, verrüköz hiperplazi, proliferatif verrüköz lökoplaki ve verruka vulgarisin de içinde bulunduğu bazı benign epitelyal lezyonların verrüköz skuamöz hücreli karsinomun prekürsör lezyonları olarak kabul edildiği ve verrüköz skuamöz hücreli karsinomun ayırıcı tanısında önemli olduğu bildirilmektedir (9).

Nonkeratinize skuamöz papillom genellikle 5 yaş altı çocuklarda her iki cinsiyette eşit ve 20-40 yaşlarında erişkinlerde ve erkeklerde kadınlardan daha sık görülür. En sık larinskte vokal kordlarda görülür. Genellikle HPV tip 6 ve 11 ile nadiren 16, 18 ve diğer tiplerle ilişkidir. En sık klinik bulgusu ses kısıklığıdır. Makroskopik olarak $1 \mathrm{~cm}$ ' den küçük genellikle multiple lezyonlar şeklinde, lobüler yüzeyli gri beyaz renkli ekzofitik ya da papiller lezyonlardır. Mikroskopik incelemede fibrovasküler korlar içeren çok sıralı benign epitel hücreleri ile döşeli papiller yapılar gözlenir. Yüzey epitelinin bazal ve parabazal hücrelerinde hiperplazi ve epitelin üst kısımlarında koilositler dikkati çeker. Nadiren epitelde değişen derecelerde atipi ve hafif, orta ya da şiddetli derecede displazi bulguları görülebilir. Verruka vulgariste dallanan fibrovasküler korlar, epitelde atipi ya da displazi bulunmazken belirgin yüzey keratinizasyonu ve belirgin keratohiyalin granülleri görülmektedir (4, $5,15,16)$.

Soliter keratinize skuamöz papillom 50 yaş altı erişkinlerde kadın ve erkeklerde eşit olarak görülür. Vokal kordlarda görülme eğilimindedir. Hastalarda en sık klinik bulgu ses kısıklığıdır. Nonkeratinize skuamöz papillomların aksine bunlar etiyolojik olarak HPV ile ilişkili olmayıp hastalarda sigara içme öyküsü bildirilmiştir. Makroskopik olarak $2 \mathrm{~cm}$ ' yi geçmeyen ekzofitik ya da papiller lezyonlar şeklindedir. Yüzeyinde keratinizasyon bulunan fibrovasküler korlar içeren çok katlı benign skuamöz epitel ile döşeli papiller yapılardan oluşur. Keratinizasyon ortokeratoz ve parakeratoz şeklindedir. Keratohiyalin granülleri bulunur ancak koilositler içermez. Genellikle sitolojik atipi içermez ancak atipi ve displazi içeren olgular bildirilmiştir $(4,7,15)$.

Verruka vulgaris ile verrüköz karsinomun ayırıcı tanısı önemli ve zordur. Verrüköz karsinom erişkin yaşlarda ve erkeklerde daha sık görülür. Baş boyun bölgesinde en sık görüldüğü yer oral kavite olup en sık bukkal mukoza ve gingivada görülür. Larinks ise baş boyun bölgesinde ikinci sıklıkta görüldüğü yerdir. Tüm larinks kanserlerinin \%1-4' ünü oluşturur. Larinkste en sık glottik alanda anterior vokal kordlarda daha az sıklıkta ise supraglottis, hipofarinks ve subglottiste görülür. En sık bulgusu ses kısıklığıdır. Etiyolojisinde sigara kullanımı ve HPV (en sık tip 16 ve 18, daha az sıklıkta 6 ve 11) bulunur. Makroskopik olarak 9-10 cm' ye kadar büyüklükte ekzofitik, gri beyaz renkli sert kitle şeklindedir. Mikroskopik incelemede yüzeyinde belirgin kilise kulesi görünümünde hiperkeratoz tabakası içeren benign görünümlü displastik özellikler ya da mitoz içermeyen üniform skuamöz hücre proliferasyonundan oluşur. Keratinizasyon belirgindir ancak verruka vulgariste görülen bol keratohyalin granüller içeren granüler tabaka burada bulunmaz. Geniş tabanlı reteler infiltratif olmayıp itici tarzdadır. Ayrıca verrüköz karsinomda stromada yoğun lenfosit, plazma hücreleri ve histiyositlerden oluşan inflamatuar infiltrat gözlenir. Yüzey epiteli ile sınırlı olan verruka vulgarisin aksine verrüköz karsinomda stromal invazyon görülür $(4,7,15)$. 
Literatürde şimdiye kadar tanımlanmış 10' un üzerinde laringeal verruka vulgaris olgusu bulunmaktadır (10-14). Bildirilen hastaların tümü lokal cerrahi ile tedavi edilmiştir. Hastaların hiçbirinde hastalığın tekrarlaması görülmemiştir. Bizim hastamız da lokal cerrahi ile tedavi edilmiş olup bir yıl süresinde tekrarlama görülmemiştir.

Sonuç olarak larinkste görülen verruka vulgaris benign bir lezyondur ve skuamöz papillom gibi diğer benign lezyonlardan ve özellikle tedavileri farklı olduğu için malign bir tümör olan verrüköz karsinomdan ayrımı önemlidir.

\section{KAYNAKLAR}

1. Pfister H, Fuchs PG. Papiloma viruses particles, genome organizationand proteins. In: Syrjanen K ed. Papilloma Viruses and Human disease. Berlin: Springer-Verlag; 1987:1-18.

2. Arends MJ, Wyllie AH, Bird CC. Papillomaviruses and human cancer. Hum Pathol 1990;21:686-698.

3. Fechner RE, Mills SE. Verruca vulgaris of the larynx:a distinctive lesion of probable viral origin confused with verrucous carcinoma. Am J Surg Pathol 1982;6:357-362.

4. Atlas of Head and Neck Patohlogy. Bruce M. Wenig Part 3, Chapter 13, Second Edition. pp 452.

5. De villiers EM. Heterogeneity of the human papilloma virus group. J Virol 1991;63:4898-4903.

6. Adler-Storthz k, Newland JR, Tessin BA, et al. Identification of human papilloma virus types in oral verruca vulgaris. J Oral Pathol 1986;15:230-233.

7. Eversole LR, Laipis PJ, Green TL. Human papilloma virus type 2 DNA in oral and labial verruca vulgaris. J Cutan Pathol 1987;14:319-325.

8. Tsutsumi K, Nakajima T, Gotoh M, et al. In sitı hybridization and immunohistochemical study of human papilloma virus infection in adult laryngeal papillomas. Laryngoscope 1989;99:80-85.

9. Batsakis JG, Hybels R, Crissman JD, Rice DH. The pathology of head and neck tumors. : verrucous carcinoma. Head Neck Surg 1982; 5:29-38.

10. Barnes L, Yunis Ej, Krebs FJ, Sonmez-Alpan E. Verruca vulgaris of the larynx. Demonstration of human papillomavirus types 6/11 by in situ hybridization. Arch Pathol Lab Med 1991;115:895-899.

11. Acar B, Babademez MA, Karabulut $H$, et al. An unusual cause of dysphonia: laryngeal verruca vulgaris. B-ENT 2009;5:183-187.

12. Topdağ M, Erdoğan S, Kara A, Derin S. Laryngeal verruca vulgaris. BMJ Case Rep 2015;pii:bcr2014207773.

13. Sagit M, Hira I, Polat $H$, Akay E, Yaşar M. A rare cause of hoarseness: Laryngeal verruca vulgaris. The Journal of Craniofacial Surgery 2016;27:397-398.

14. Yıldırım S, Tezcaner ZÇ, Fatullayev T, Dursun G. Laryngeal verruca vulgaris presenting with dysphonia: A case report. Turk Arch Otorhinolaryngol 2017;55:184-186.

15. Head and Neck Pathology. A Volume in the Series Foundations In Diagnostic Pathology. Lester D.R. Thompson, John R. Goldblum. Chapter 6, Second Edition. pp 154.

16. Diagnostic Pathology Head and Neck. Thompson and Wenig, Second Edition Section 3, pp 258. 